\title{
Phytosociological observations on tree species diversity of an urban tropical dry deciduous forest of central India
}

\author{
Dharmendra Dugaya $\oplus^{1} *$ P.V. Kiran $\oplus^{1}$ Rajnish K. Singh $\oplus^{l}$ Manmeet Kaur $\circledast^{1}$ Pradeep Chaudhry $\oplus^{1}$
}

${ }^{1}$ Indian Institute of Forest Management, Post Box No. 357, Nehru Nagar, Bhopal - 462003, Madhya Pradesh, India

\begin{abstract}
Original Article
*Corresponding author:

dugayad@iifm.ac.in

Keywords:

Biodiversity indices

Basal area

Importance value index

Vegetation dynamics

Tree diversity

Conservation

Palavras-chave:

Índices de biodiversidade

Área basal

ABSTRACT: We analyzed phytosociological characteristics of a tropical dry deciduous forest located in an urban environment of Indian Institute of Forest Management (IIFM) Campus in the capital city of Bhopal of Madhya Pradesh state, Central India. Comparison has been made among the tree community characteristics during the years 1988, 2002 and 2020 in terms of tree species composition, stem density, basal area and Importance Value Index (IVI). At the time of the establishment of the institute in 1988, the forest area resembled a degraded dry scrubland. Due to continuous care/protection, plantation activities, degraded forest recovered remarkably, ecological processes evolved favorably with canopy cover reaching over $60 \%$ in some patches and about $50 \%$ in general over most of the campus. During last two decades, tree density increased from 319 to 525 stem ha $^{-1}$ indicating an increase of $64 \%$ whereas basal area increased from $18470.79 \mathrm{~cm}^{2} \mathrm{ha}^{-1}$ to $29782.31 \mathrm{~cm}^{2} \mathrm{ha}^{-1}$, an increase of about $61 \%$. Fabaceae family represented $26.4 \%$ of the tree community, followed by Combretaceae $(11.76 \%)$. Shannon-Wiener index (1.31), Simpson index (0.93) and evenness index $(0.85)$ are within the reported ranges for similar forest type of dry deciduous nature in India. The results of the present study will help forest managers in the conservation planning of urban tropical forest ecosystem of central India.
\end{abstract}

Índice de valor de

importância

Dinâmica da vegetação

Diversidade de árvores

Conservação

Received on

$2020 / 04 / 28$

Accepted on

2020/07/30

Published in

2020/11/02

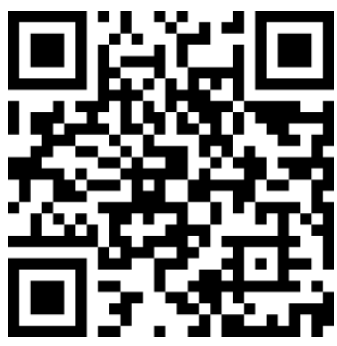

DOI:

http://dx.doi.org/10.34062/af s.v7i3.10252

\section{Observações fitossociológicas sobre a diversidade de espécies arbóreas de uma floresta tropical decídua urbana urbana da Índia central}

RESUMO: Nós analisamos as características fitossociológicas de uma floresta tropical seca decidual localizada em um ambiente urbano do campus do Instituto Indiano de Manejo Florestal (IIFM) na capital do estado de Bhopal, Madhya Pradesh, Índia Central. A comparação foi feita entre as características da comunidade de árvores durante os anos de 1988, 2002 e 2020 em termos de composição de espécies de árvores, densidade do caule, área basal e Índice de Valor de Importância (IVI). Na época da criação do instituto em 1988, a área florestal assemelhava-se a um matagal seco degradado. Devido ao cuidado / proteção contínua, atividades de plantio, floresta degradada recuperou-se notavelmente, os processos ecológicos evoluíram favoravelmente com cobertura de dossel atingindo mais de $60 \%$ em alguns fragmentos e cerca de $50 \%$ em geral na maior parte do campus. Durante as últimas duas décadas, a densidade arbórea aumentou de 319 para 525 caule ha- 1 indicando um aumento de $64 \%$ enquanto a área basal aumentou de $18.470,79 \mathrm{~cm} 2$ ha-1 para $29782,31 \mathrm{~cm} 2 \mathrm{ha}-1$, um aumento de cerca de 61\%. A família Fabaceae representou 26,4\% da comunidade arbórea, seguida por Combretaceae (11,76\%). O índice de ShannonWiener $(1,31)$, o índice de Simpson $(0,93)$ e o índice de uniformidade $(0,85)$ estão dentro dos intervalos relatados para tipo de floresta semelhante de natureza decídua seca na Índia. Os resultados do presente estudo ajudarão os gestores florestais no planejamento da conservação do ecossistema de floresta tropical urbana da Índia central. 


\section{Introduction}

India is a developing nation having a very high density of human beings and cattle. After China, the country supports the highest global human population. Out of 0.64 million inhabited villages, about 27 per cent are located around forests in various states of the country (FSI 2013). Tropical nations have among the world's highest population growth rates; there tends to be a strong positive co-relationship between population size and annual deforestation (Laurance 1999). In most developing countries, including India, even protected forest experiences extensive anthropogenic disturbances (Singh et al. 1997).

Condition of these forests particularly near the urban centres is more alarming due to constant demand for fuel-wood and fodder by the people living around the forested areas. The present study has been conducted in a forested area located in a densely populated capital city of Bhopal in a central Indian state (Madhya Pradesh) and focused on analyzing frequency, density and abundance pattern of tree species in the urban forest. We have documented changes in composition, structure and diversity of forest at an urban site where boundary protection was enforced from the year 1988 and is still continuing. A comparison has been made of the vegetation situations among the periods 1988-20022020.

The study is an academic attempt to highlight the progression of an urban forest ecosystem comprising mostly of native plant species of tropical dry decidous forest origin. The municipal and urban development authorities in India are responsible for creating and maintaining urban parks/gardens and other recreational spaces in city areas as per the $74^{\text {th }}$ amendment of the Indian Constitution in 1992. But these authorities generally lack technical expertise for undertaking phytosociological analysis of the urban vegetation under their jurisdiction. The present study will contribute in planning and management of urban green cover broadly in tropical dry deciduous areas.

\section{Material and Methods}

The study area (Indian Institute of Forest Management Bhopal, India) is covered under Vindhyan hill range with gentle slopes ranging from $0^{\circ}-5^{\circ}$ and at some places as much as $35^{\circ}$. The site is generally covered by sandstone of Vindhyan formation. Alluvial soil occurs at foothills, and some moisture-loving species have been planted at foothills near main campus gate like Alstonia scholaris (L.) R. Br., Terminalia arjuna (Roxb), Sygium cumini L. and Bauhinia racemosa L. The average rainfall is around $1000 \mathrm{~mm}$, mostly received during the rainy season (July to September). The minimum temperature during winter falls to $7^{\circ} \mathrm{C}$ and maximum in summer rises to $45^{\circ} \mathrm{C}$ (Kotwal et al., 2004).

IIFM campus area (80.64 ha) has been categorized into four categories using "Enhanced vegetation index" (EVI). EVI is a tool similar to Normalized Difference Vegetation Index (NDVI) and can be used to quantify vegetation greenness over an area using satellite imageries and Geographical Information System (GIS). Table 1 presents the broad categories of the study area, which is surrounded by dense human habitation on one side and natural water bodies on the other three sides.

A total of 47 plots of $10 \mathrm{~m} \times 10 \mathrm{~m}$ were laid randomly over three types of forest density areas mentioned in Table 1during January/February 2020. The overall height and girth breast height $(\mathrm{GBH})$ of all tree species with GBH above $20 \mathrm{~cm}$ were recorded and identified to the species level. Christen hypsometer was used for measuring height whereas measuring tape was used for recording GBH of trees.

Table1. Categorization of study area according to forest density

\begin{tabular}{llll}
\hline S No & Category of area & Canopy density & Area (ha) \\
\hline 1 & Dense forest* & 0.70 to 0.80 & 19.61 \\
2 & Moderately dense forest** & 0.40 to 0.70 & 29.36 \\
3 & Grassland and scrub forest*** & 0.10 to 0.40 & 26.46 \\
4 & Built-up area & Below 0.10 & 05.21 \\
& & & Total 80.64 \\
\hline
\end{tabular}

*Dense: Canopy cover $>70 \%$; **Moderately dense: $40-70 \%$;**Grassland \& Scrub: 10-40 \% canopy cover (Adotded from: Forest Survey of India, Govt. of India classification). 


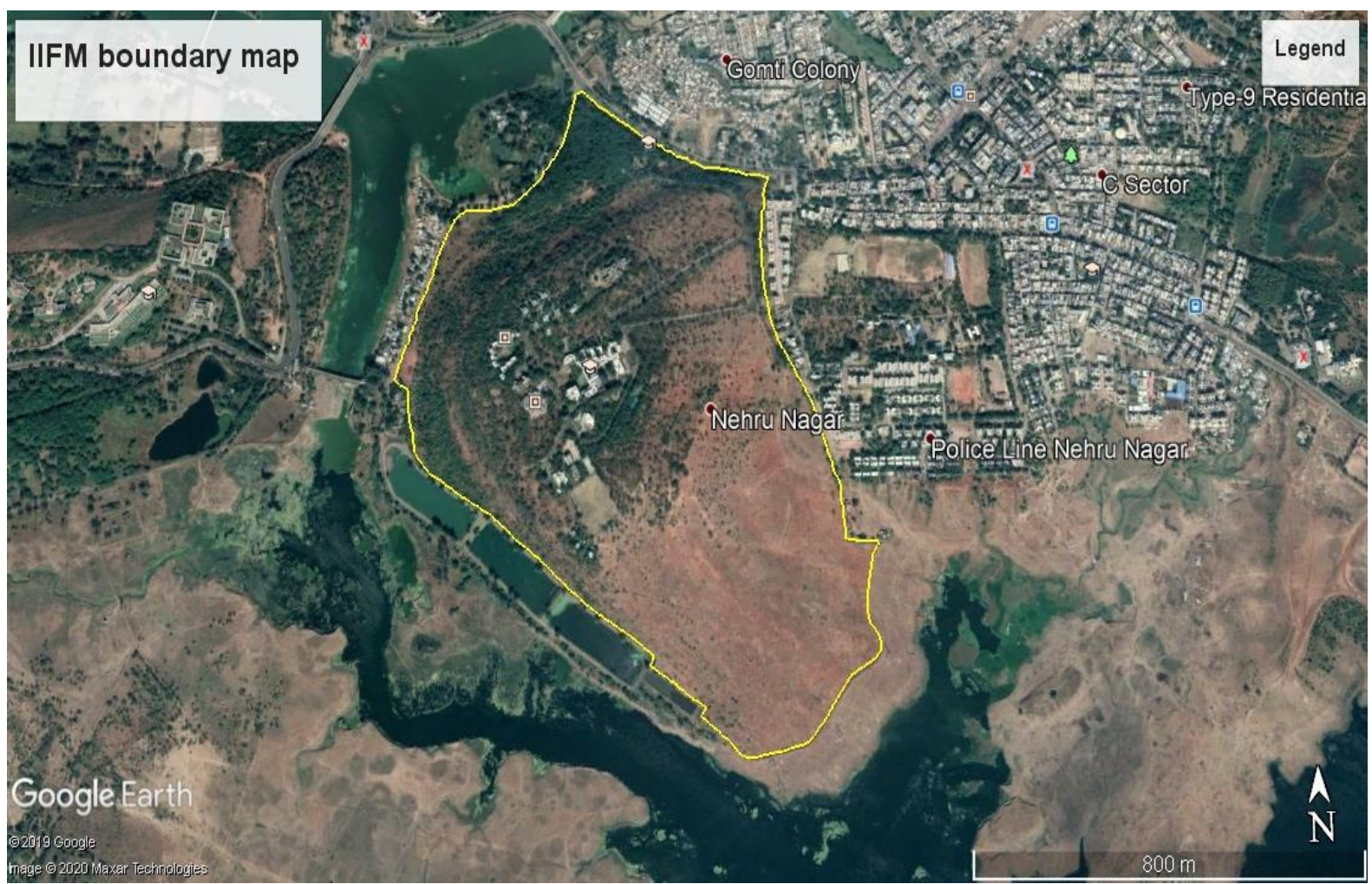

Figure 1. IIFM campus view with surrounding features

Importance values of tree species are based on frequency (calculated from the number of plots), density (calculated from the number of individuals) and dominance or abundance (calculated from the basal area).The concept of Importance Value Index has been developed for expressing the dominance and ecological success of any species, with a single value. The IVI was calculated by the summation of relative values of frequency, density and dominance (Curtis and McIntosh 1950; Curtis and Cottam 1956; Phillips 1959). Following formulae were used for estimating these parameters:

$$
\begin{gathered}
\text { Density }=\frac{\text { Total number of individual of a species }}{\text { Total number of plots studied }} \\
\text { Frequency }(\%)=\frac{\text { No. of plots of occurrence of a species }}{\begin{array}{c}
\text { Total number of plots studied } \\
\times 100
\end{array}}
\end{gathered}
$$

Abundance $=\frac{\text { Total number of individual of a species }}{\text { Number of plots of occurrence }}$

Relative Frequency $=\frac{\text { Frequency of a species }}{\text { Frequency of all the species }} \times 100$

Relative Density $=\frac{\text { Density of a species }}{\text { Density of all the species }} \times 100$

$$
\text { Relative Dominance }=\frac{\text { Basal area of a species }}{\text { Basal area of all the species }} \times 100
$$

Importance Value Index (IVI) was estimated separately for each species of the community. A species, which attains the highest importance value in the site, is the dominant and the species with the lowest importance value is considered as least dominant species of the given area.

$$
\text { IVI = Relative Frequency + Relative Density + Relative Dominance }
$$

The data was also used to compute species diversity $\left(\mathrm{H}^{\prime}\right)$ of different tree species and was estimated using the Shannon - Wiener index (Shannon and Wiener 1963):

$$
\mathrm{H}^{\prime}=\sum_{\mathrm{i}=1}^{\mathrm{s}} \mathrm{p}_{\mathrm{i}} \ln \mathrm{p}_{\mathrm{i}}
$$

Where pi is the proportion of individuals found in species i. For a well-sampled community, we can estimate this proportion as $p_{i}=n_{i} / N$, where ni is the number of individuals in species $\mathrm{i}$ and $\mathrm{N}$ is the total number of individuals in the community. Since by definition the $\mathrm{p}_{\mathrm{i}} \mathrm{s}$ will all be between zero and one, the natural $\log$ makes all of the terms of the summation negative, which is why we take the inverse of the sum.

Species dominance (D) was calculated following the equation by Simpson (1949): 


$$
\mathrm{D}=\frac{\sum \mathrm{n}(\mathrm{n}-1)}{\mathrm{N}(\mathrm{N}-1)}
$$

Where, $\mathrm{n}$ is number of individuals of a species and; $\mathrm{N}$ is total number of species

Equitability of evenness refers to the degree of the relative dominance of each species in that area. Its estimation was done using Pielou (1966):

$$
\text { Eveness }=\frac{\mathrm{H}^{\prime}}{\mathrm{H}_{\max }^{\prime}}
$$

Where, $H^{\prime}=$ Shannon index, $H^{\prime}{ }_{\text {max }}$ is $\ln S, S=$ number of species

Referred the "binomial system" or "binomial nomenclature" for assigning scientific names to plants, whereby the first word is the genus name and the second one the species name or "specific epithet".

\section{Results and discussion}

Before the establishment of the institute, the area was exposed to uncontrolled grazing and firewood collection by the nearby population (Figure 2 ). The natural vegetation was represented by Lantana camara L., Carissa carandas L. and few hacked trees of Butea monosperma (Lam.) Taub., Zizyphus xylopyrus (Retz.) Willd, Diospyros melanoxylon Roxb., Wrightia tincroria (R.Br.) and Lagerstroemia parviflora Roxb (Kotwal et al. 2004). With the establishment of the institute in 1988 , protection to the area was given by boundary wall; coppice shoots could develop from rootstocks of tree species present in the area.

A phytosociological study was undertaken by Kotwal et al. (2004) during the year 2002 to work out density, frequency, dominance and Importance value index (IVI) of tree species of the campus forest. Finer details are given in Table 2. After a gap of eighteen years, another research study was undertaken by a group of Post Graduate Diploma in Forestry Management (PGDFM) of the IIFM to find out the current status of forest in terms of phytosociological attributes like frequency, density, dominance, importance value index of tree species, species composition and biodiversity indices for the campus forest. The basic idea was to find out the changes in species composition, dominance, basal area and density over a period of nearly two decades.

In the present study, the vegetation data were analyzed for 35 tree species and 19 families in the study area (Table 3). Fabaceae family represented $26.4 \%$ of the tree community at IIFM campus followed by Combretaceae $(11.76 \%)$ and Apocynaceae, Myrtaceae, Rhamnaceae \& Rubiaceae $(5.88 \%$ each). Families Rutaceae, Santalaceae, Sapindaceae, Sapotaceae, Sterculiaceae, Ulmaceae, Lythraceae, Meliaceae,
Moraceae, Anacardiaceae, Annonaceae, Bombacaceae, Ebenaceae represented $2.94 \%$ each. The presence and flourishing of Fabaceae, a nitrogen-fixing family in IIFM campus where the hillock comprised of a thin veneer of soil cover on a gentle slope and sheet rocks with joints and fractures are exposed over moderate to steep slopes (Kotwal et al. 2004) have resulted in a conducive environment for the colonization of other associated species.

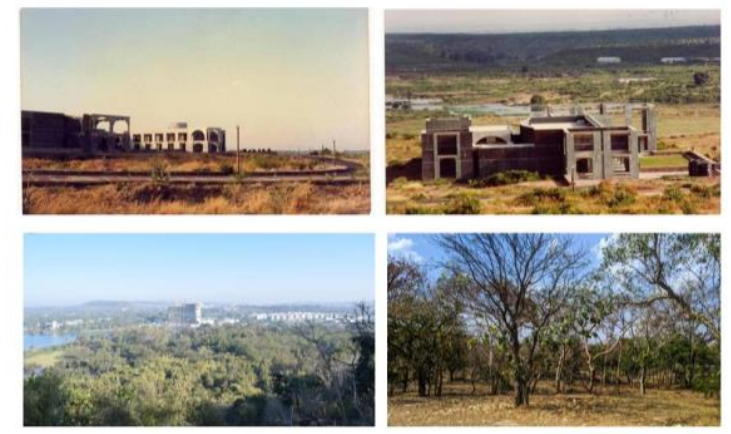

Figure 2. A panoramic view of the institute's dry scrub landscape in 1988 (upper two figures); Dense forest cover in the study area with high human density areas in the background (lower left figure); A view of moderately dense forest cover over study area (lower right figure).

The Importance Value Index (IVI) depicts the phytosociological structure of a species in its totality in the community. The IVI is of great help in getting the overall picture of the ecological importance of a species. The top ten dominant tree species of the study area in descending order of IVI are Lannea coromandelica Houtt (48.60), Diospyros melonoxylon Roxb (23.91), Wrightia tinctoria R.Br (23.39), Leucaena leucocephala (Lam) de Wit (21.27), Azadirachta indica A. Juss (18.35), Anogeissus latifolia Roxb. Ex DC (16.03), Holoptelea integrifolia Planch (14.22), Acacia catechu LF Willd (12.37), Butea monosperma (Lam.) Taub (11.22) and Miliusa tomentosa Roxb (11.15). At the same time density-wise the sequence of top ten species is Lannea coromandelica Houtt, Diospyros melanoxylon Roxb, Leucaena leucocephala (Lam) de Wit, Azadirachta indica A. Juss, Wrightia tinctoria R.Br, Acacia catechu LF Willd, Anogeissus latifolia Roxb. Ex DC, Butea monosperma (Lam.), Lagerstroemia parviflora Roxb and Miliusa tomentosa Roxb (Table 3).

Comparing Tables 2 and 3, few findings emerge out. Lannea coromandelica Houtt has established itself as the most dominant tree species of the area in terms of density, frequency and dominance between the periods 2002 to 2020. This species was ranked at number 4 in terms of density and number 3 in terms of IVI earlier (Table 2). It is a soft-wood species, which comes up over typical hillocks of Vindhyan range. The species derives its 
name from Coromandel region of South India. Locally in central India, it is called as Gurjan and/or Moyan, where the tree becomes almost leafless in Feb-March months and new leaves appear quite late after inflorescence in March-April months. Wood is mainly used for making packing boxes.

Table 2. Phytosociology of vegetation: Trees 20cm GBH and above (adopted from Kotwal et al. 2004).

\begin{tabular}{|c|c|c|c|c|c|c|c|c|}
\hline $\begin{array}{l}\text { S. } \\
\text { No. }\end{array}$ & Name of Species & F \% & $\begin{array}{l}\text { D no. } \\
\text { ha }^{-1}\end{array}$ & $\begin{array}{l}\text { BA } \\
\mathrm{cm}^{2} \mathrm{ha}^{-1}\end{array}$ & $\begin{array}{l}\text { RF } \\
\%\end{array}$ & $\begin{array}{l}\text { RD } \\
\%\end{array}$ & $\begin{array}{l}\text { R Dom } \\
(\%)\end{array}$ & IVI \\
\hline 1. & Acacia catechu (L.F.) Willd. & 10.00 & 9.99 & 342.34 & 3.95 & 3.13 & 1.85 & 8.93 \\
\hline 2. & Aegle marmelos L. Correa & 3.33 & 3.33 & 71.65 & 1.32 & 1.04 & 0.39 & 2.75 \\
\hline 3. & Ailanthus excels Roxb. & 3.33 & 3.33 & 390.12 & 1.32 & 1.04 & 2.11 & 4.47 \\
\hline 4. & Anogeissus latifolia Roxb.ex DC. & 13.33 & 19.98 & 1194.23 & 5.26 & 6.25 & 6.47 & 17.98 \\
\hline 5 & Azadirachta indica A. Juss. & 13.33 & 16.65 & 613.03 & 5.26 & 5.21 & 3.32 & 13.79 \\
\hline 6 & Bombax ceiba $\mathrm{L}$. & 3.33 & 3.33 & 199.04 & 1.32 & 1.04 & 1.08 & 3.44 \\
\hline 7 & Butea monosperma (Lam.) Taub. & 6.67 & 6.66 & 270.69 & 2.63 & 2.08 & 1.47 & 6.18 \\
\hline 8 & Careya arborea Roxb. & 3.33 & 3.33 & 71.65 & 1.32 & 1.04 & 0.39 & 2.75 \\
\hline 9 & Cassia fistula L. & 3.33 & 3.33 & 199.04 & 1.32 & 1.04 & 1.08 & 3.44 \\
\hline 10 & Dalbergia paniculata Roxb. & 6.67 & 9.99 & 469.73 & 2.63 & 3.3 & 2.54 & 8.30 \\
\hline 11 & Dalbergia sissoo Roxb. & 6.67 & 9.99 & 660.81 & 2.63 & 3.13 & 3.58 & 9.33 \\
\hline 12 & Diospyros melanoxylon Roxb. & 20.00 & 23.31 & 1393.27 & 7.89 & 7.29 & 7.54 & 22.73 \\
\hline 13 & Emblica officinalis Gaertn. & 6.67 & 13.32 & 859.85 & 2.63 & 4.17 & 4.66 & 11.45 \\
\hline 14 & Erythrina suberosa Roxb. & 3.33 & 3.33 & 71.65 & 1.32 & 1.04 & 0.39 & 2.75 \\
\hline 15 & Gardenia latifolia Aiton & 6.67 & 9.99 & 342.34 & 2.63 & 3.13 & 1.85 & 7.61 \\
\hline 16 & Hardwickia binata Roxb. & 6.67 & 6.66 & 589.16 & 2.63 & 2.08 & 3.19 & 7.90 \\
\hline 17 & Holoptelea integrifolia Planch. & 10.00 & 13.32 & 732.46 & 3.95 & 4.17 & 3.97 & 12.08 \\
\hline 18 & Lagerstroemia parviflora Roxb. & 16.67 & 23.31 & 1202.19 & 6.58 & 7.29 & 6.51 & 20.38 \\
\hline 19 & Lannea coromandelica (Houtt.) & 20.22 & 19.98 & 1449.01 & 7.89 & 6.25 & 7.84 & 21.99 \\
\hline 20 & $\begin{array}{l}\text { Leucaena leucocephala (Lam) de } \\
\text { Wit. }\end{array}$ & 3.33 & 9.99 & 469.73 & 1.32 & 3.13 & 2.54 & 6.98 \\
\hline 21 & Miliusa tomentosa Roxb. & 20.22 & 23.31 & 1648.05 & 7.89 & 7.29 & 8.92 & 24.11 \\
\hline 22 & Mitragyna parvifolia (Roxb.) Korth & 10.00 & 13.32 & 859.85 & 3.95 & 4.17 & 4.66 & 12.77 \\
\hline 23 & Prosopis juliflora (Sw.) DC. & 3.33 & 3.33 & 71.65 & 1.32 & 1.04 & 0.39 & 2.75 \\
\hline 24 & Pterocarpus marsupium Roxb. & 3.33 & 9.99 & 788.2 & 1.32 & 3.13 & 4.27 & 8.71 \\
\hline 25 & Samanea saman (Jacq.) Merr. & 6.67 & 6.66 & 589.16 & 2.63 & 2.08 & 3.19 & 7.90 \\
\hline 26 & Santalum album $\mathrm{L}$. & 3.33 & 3.33 & 71.65 & 1.32 & 1.04 & 0.39 & 2.75 \\
\hline 27 & Schleichera oleosa (Lour.) & 6.67 & 6.66 & 398.08 & 2.63 & 2.08 & 2.16 & 6.87 \\
\hline 28 & Sterculiaurens(Roxb.) & 3.33 & 3.33 & 390.12 & 1.32 & 1.04 & 2.11 & 4.47 \\
\hline 29 & Wrightia tinctoria (R.Br.) & 20.22 & 19.98 & 1449.01 & 7.89 & 6.25 & 7.84 & 21.99 \\
\hline \multirow[t]{2}{*}{30} & Zizyphus xylopyrus (Retz.) Willd & 10.00 & 16.65 & 613.03 & 3.95 & 5.21 & 3.32 & 12.47 \\
\hline & & 253.33 & 319.7 & 18470.79 & 100 & 100 & 100 & 300 \\
\hline
\end{tabular}

F:Frequency; RF: Relative Frequency; D:Density; RD: Relative Density; BA: Basal Area; RDom: Relative Dominance; IVI: Importance Value Index

Another important point is about the emergence of Leucaena leucocephala (Lam) de Wit as one of the top dominant species in the forest during the last few years. Earlier the IVI rank of this species was $19^{\text {th }}$ (IVI score 6.98) and presently this species is occupying $4^{\text {th }}$ rank with IVI score of 21.27 (Tables 2 and 3). Leucaena leucocephala (Lam) de Wit (locally called Subabul) is very fastgrowing tree species coming naturally in the institute after initial introduction in the early nineties. This species produces a large number of seed-bearing pods during the months of January-
February each year and seeds require bare minimum soil moisture and soil depth for germination, prompting good regeneration. A major disadvantage of the species is its suppressing and colonizing nature as it generally does not allow other native species to flourish under it. Hence due precautions have to be taken by forest managers to check its further spread in the campus. However, the clonal version of the species is very useful in agro-forestry plantations in south India, where its wood is used by paper and pulp industries. 
Dugaya et al.

Table 3: Phytosociology of campus vegetation during 2020

\begin{tabular}{|c|c|c|c|c|c|c|c|c|c|}
\hline S. No. & Name of Species & Family & F \% & $\begin{array}{l}\text { D } \\
\text { ha }^{-1}\end{array}$ & $\begin{array}{l}\mathbf{B A} \\
\mathbf{c m}^{2}\end{array}$ & $\mathbf{R F}$ & RD & R Dom & IVI \\
\hline 1. & Acacia catechu (L.F.) Willd. & Fabaceae & 14.89 & 8.51 & 621.26 & 5.43 & 4.86 & 2.09 & 12.37 \\
\hline 2. & $\begin{array}{l}\text { Acacia leucophloea (Roxb.) } \\
\text { Willd. }\end{array}$ & Fabaceae & 2.13 & 85.11 & 84.24 & 0.78 & 0.81 & 0.28 & 1.87 \\
\hline 3. & Aegle marmelos L. Correa & Rutaceae & 8.51 & 2.13 & 711.01 & 3.10 & 3.64 & 2.39 & 9.13 \\
\hline 4. & $\begin{array}{l}\text { Anogeissus latifolia Roxb. Ex } \\
\text { DC. }\end{array}$ & Combretacea & 12.77 & 48.94 & 1219.15 & 4.65 & 7.29 & 4.09 & 16.03 \\
\hline 5. & Azadirachta indica A.Juss. & Meliaceae & 17.02 & 8.51 & 2170.81 & 6.20 & 4.86 & 7.29 & 18.35 \\
\hline 6. & Bauhinia variegata $\mathrm{L}$. & Fabaceae & 4.26 & 25.53 & 141.43 & 1.55 & 1.21 & 0.47 & 3.24 \\
\hline 7. & Bombax ceiba L. & Bombacaceae & 4.26 & 10.64 & 153.03 & 1.55 & 0.81 & 0.51 & 2.87 \\
\hline 8. & $\begin{array}{l}\text { Butea monosperma (Lam.) } \\
\text { Taub. }\end{array}$ & Fabaceae & 12.77 & 6.38 & 1227.94 & 4.65 & 2.43 & 4.12 & 11.20 \\
\hline 9. & Careya arborea Roxb. & Myrtaceae & 4.26 & 19.15 & 91.72 & 1.55 & 0.81 & 0.31 & 2.67 \\
\hline 10. & Carrisa carandas $\mathrm{L}$. & Apocynaceae & 2.13 & 38.30 & 53.82 & 0.78 & 0.40 & 0.18 & 1.36 \\
\hline 11. & Cassia fistula $\mathrm{L}$. & Fabaceae & 2.13 & 21.28 & 45.86 & 0.78 & 0.40 & 0.15 & 1.33 \\
\hline 12. & Dalbergia latifolia Roxb. & Fabaceae & 4.26 & 44.68 & 382.32 & 1.55 & 0.81 & 1.28 & 3.64 \\
\hline 13. & Dalbergia paniculata Roxb. & Fabaceae & 4.26 & 25.53 & 509.55 & 1.55 & 1.62 & 1.71 & 4.88 \\
\hline 14. & Dalbergia sissoo Roxb. & Fabaceae & 2.13 & 4.26 & 326.11 & 0.78 & 0.40 & 1.09 & 2.28 \\
\hline 15. & Diospyros melanoxylon Roxb. & Ebenaceae & 23.40 & 2.13 & 1808.38 & 8.53 & 9.31 & 6.07 & 23.91 \\
\hline 16. & Erythrina suberosa Roxb. & Fabaceae & 10.64 & 19.15 & 470.40 & 3.88 & 2.02 & 1.58 & 7.48 \\
\hline 17. & Ficus religiosa $\mathrm{L}$. & Moraceae & 4.26 & 4.26 & 770.70 & 1.55 & 2.02 & 2.59 & 6.16 \\
\hline 18. & Gardenia gummifera L.F. & Rubiaceae & 2.13 & 6.38 & 394.12 & 0.78 & 0.81 & 1.32 & 2.91 \\
\hline 19. & Gardenia latifolia Aiton & Rubiaceae & 6.38 & 10.64 & 1135.03 & 2.33 & 4.45 & 3.81 & 10.59 \\
\hline 20. & Holoptelea integrifolia Planch. & Ulmaceae & 8.51 & 2.13 & 2829.00 & 3.10 & 1.62 & 9.50 & 14.22 \\
\hline 21. & Lagerstroemia parviflora Roxb & Lythraceae & 10.64 & 2.13 & 856.56 & 3.88 & 4.05 & 2.88 & 10.80 \\
\hline 22. & Lannea coromandelica (Houtt.) & Anacardiaceae & 34.04 & 4.26 & 5957.21 & 12.40 & 16.19 & 20.00 & 48.60 \\
\hline 23. & $\begin{array}{l}\text { Leucaena leucocephala (Lam) } \\
\text { de Wit. }\end{array}$ & Fabaceae & 23.40 & 12.77 & 1264.43 & 8.53 & 8.50 & 4.25 & 21.27 \\
\hline 24. & Manilkara hexandra (Roxb.) & Sapotaceae & 4.26 & 2.13 & 509.55 & 1.55 & 1.62 & 1.71 & 4.88 \\
\hline 25. & Miliusa tomentosa (Roxb.) & Anonaceae & 10.64 & 46.81 & 1080.59 & 3.88 & 3.64 & 3.63 & 11.15 \\
\hline 26. & Santalum album $\mathrm{L}$. & Santalaceae & 2.13 & 8.51 & 71.66 & 0.78 & 0.40 & 0.24 & 1.42 \\
\hline 27. & Schleichera oleosa (Lour.) & Sapindaceae & 2.13 & 4.26 & 62.42 & 0.78 & 0.40 & 0.21 & 1.39 \\
\hline 28. & Sterculia urens (Roxb.) & Sterculiaceae & 6.38 & 8.51 & 238.22 & 2.33 & 1.62 & 0.80 & 4.74 \\
\hline 29. & Syzygium cumini L. & Myrtaceae & 2.13 & 4.26 & 161.23 & 0.78 & 0.40 & 0.54 & 1.72 \\
\hline 30. & Terminalia alata (Roth) & Combretacea & 2.13 & 4.26 & 412.74 & 0.78 & 0.40 & 1.39 & 2.57 \\
\hline 31. & Terminalia arjuna (Roxb.) & Combretacea & 2.13 & 23.40 & 672.77 & 0.78 & 0.81 & 2.26 & 3.84 \\
\hline
\end{tabular}




\begin{tabular}{|c|c|c|c|c|c|c|c|c|c|}
\hline \multicolumn{2}{|c|}{ S. No. Name of Species } & \multirow{2}{*}{$\begin{array}{l}\text { Family } \\
\text { Combretacea }\end{array}$} & \multirow{2}{*}{$\begin{array}{l}\text { F \% } \\
2.13\end{array}$} & \multirow{2}{*}{$\begin{array}{l}\mathbf{D} \\
\mathbf{h a}^{-1} \\
2.13\end{array}$} & \multirow{2}{*}{$\begin{array}{l}\text { BA } \\
\mathbf{c m}^{2} \\
379.06\end{array}$} & \multirow{2}{*}{$\begin{array}{l}\mathbf{R F} \\
0.78\end{array}$} & \multirow{2}{*}{$\begin{array}{l}\text { RD } \\
0.40\end{array}$} & \multirow{2}{*}{$\begin{array}{l}\text { R Dom } \\
1.27\end{array}$} & \multirow{2}{*}{$\begin{array}{l}\text { IVI } \\
2.45\end{array}$} \\
\hline 32. & $\begin{array}{l}\text { Terminalia bellirica (Gaertn.) } \\
\text { Roxb. }\end{array}$ & & & & & & & & \\
\hline 33. & Wrightia tinctoria (R.Br.) & Apocynaceae & 14.89 & 2.13 & 2698.44 & 5.43 & 8.91 & 9.06 & 23.39 \\
\hline 34. & Zizyphus mauritiana Lam. & Rhamnaceae & 4.26 & 2.13 & 207.86 & 1.55 & 1.21 & 0.70 & 3.46 \\
\hline \multirow[t]{2}{*}{35.} & Zizyphus xylopyrus (Retz.) & Rhamnaceae & 2.13 & 4.26 & 63.69 & 0.78 & 0.81 & 0.21 & 1.80 \\
\hline & & & 274.47 & 7525.53 & 29782.3 & 100 & 100 & 100 & 300 \\
\hline
\end{tabular}

F:Frequency; RF: Relative Frequency; D: Density; RD: Relative Density; BA: Basal Area; RDom: Relative Dominance; IVI: Importance Value Index

Overall basal area $\left(\mathrm{cm}^{2} \mathrm{ha}^{-1}\right)$ increased from 18470.79 to 29782.31 , an increase of about $61 \%$ in about two decades. Based on the professional experience of the first and last authors as forester in India, it is mentioned that this increment in basal area is quite satisfactory from tropical dry deciduous forest ecosystem point of view. Specieswise, the basal area has increased about 4.5 times for Butea monosperma (Lam.) Taub., 4 times for Holoptelia integrifolia Planch, 3.5 times in respect of Azadirachta indica A.Juss and 2.7 times for Leuceana leucocephala (Lam) de Wit during last 18 years (Tables 2 and 3 ).

The absolute stand density has increased from 319 trees ha-1 to 525 trees ha ${ }^{-1}$ during last two decades, indicating $64 \%$ increase, which can be considered as very good from forest management and protection point of view (Tables 2 and 3). The mean stand density of 525 trees ha $^{-1}$ is lower than reported by Reddy et al. (2007) for Simlipal Biosphere Reserve, Orissa, India but is well within the range of 276-905 stems ha $^{-1}$ reported in the tropics (Murli et al. 1996; Sundarapandian and Swamy 1997; Ghate et al. 1998).Tree density can be affected by natural calamities, anthropogenic activities and soil properties (Naidu and Kumar 2016). In our study, soil factors/properties seem to be responsible for lesser tree density as area is more or less protected from anthropogenic disturbance. Though some minor incidences of fire during summer months are common. Mean basal area of $2.97 \mathrm{~m}^{2} \mathrm{ha}^{-1}$ obtained in the current study is lesser than those reported in other studies conducted in similar types of tropical dry deciduous forests in the country (Jha and Singh 1990; Sahu et al. 2008; Bijalwan 2010; Panda et al. 2013). However, it is comparable with the range of 0.01 $2.88 \mathrm{~m}^{2} \mathrm{ha}^{-1}$ for the study conducted in tropical dry deciduous forests of Malyagiri hill ranges, Eastern Ghats (Sahu et al. 2012).

In comparison to phytosociology study conducted by Kotwal et al. (2004), Diospyros melanoxylon Roxb (23.91), Wrightia tinctoria R.Br (23.39), Anogeissus latifolia Roxb. Ex DC (16.03) continued to be the top six species as far as the IVI is concerned (Table 3 and 4), while Holoptelea integrifolia Planch (locally called Churel) has attained $7^{\text {th }}$ rank in 2020 with IVI score of 14.22 in comparison to $10^{\text {th }}$ rank in the study by Kotwal et al. (2004). The main reason is the dominance or higher basal area of the species, indicating better growth and favorable environment in the campus. This local evergreen species needs preference in future plantation schedule by forest managers in the campus. Two other native species namely Acacia catechu LF Willd (locally called Khair) and Butea monosperma (Lam.) Taub (locally known as Palas) who earlier were having $13^{\text {th }}(\mathrm{IVI}=8.93)$ and $21^{\text {st }}$ rank (IVI $=6.18$ ) respectively have been able to make among top ten dominant species in the present study of 2020 (Table 3). The comparison indicates the proliferation of species and the conducive climatic conditions in the study area.

Azadirachta indica A. Juss, locally known as Neem, has also improved its rank from $7^{\text {th }}$ to $5^{\text {th }}$ during the last two decades. All these species, except Leucaena leucocephala (Lam) de Wit. should be given preference in future plantations in the campus. Leucaena leucocephala (Lam) de Wit is an exotic species from Philippines. Major disadvantage of the species is its suppressing and colonizing nature as it generally does not allow other native species to flourish under it. Hence due precautions have to be taken by forest managers to check its spread in the area.

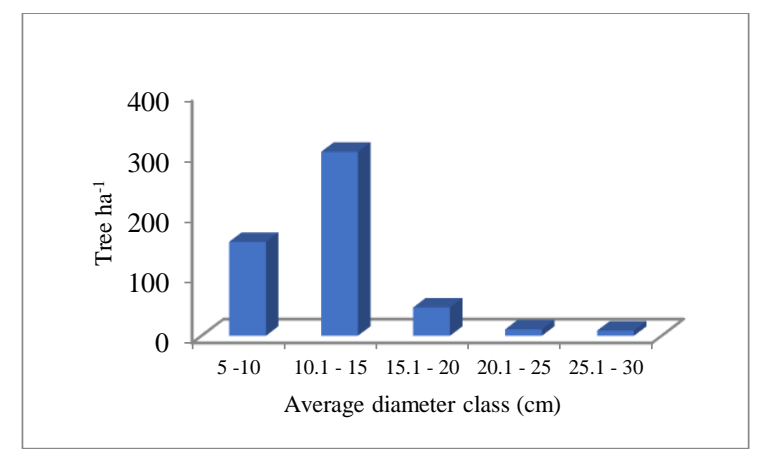

Figure 3. Average diameter class and trees $\mathrm{ha}^{-1}$ in the study area 
Distribution of trees $\mathrm{ha}^{-1}$ was categorized in to five average diameter classes of a) $5-10$; b) 10.1 15 ; c) $15.1-20$; d) 20.1-25; and e) $25.1-30 \mathrm{~cm}$. It was observed that maximum number of tree $\mathrm{ha}^{-1}$ $(57.9 \%)$ fell under the diameter class category of $10.1-15 \mathrm{~cm}$ followed by $29 \%$ in $5-10 \mathrm{~cm}$ category, $8.9 \%$ in $15.1-20 \mathrm{~cm}$ category, $2 \%$ in $20.1-25 \mathrm{~cm}$ category and rest $1.6 \%$ in $25.1-30 \mathrm{~cm}$ category (Figure 3). The analysis indicates that trees $\mathrm{ha}^{-1}$ are on lower side in higher diameter classes while lower diameter class trees would dominate the future crop composition.

\section{Roadside and other plantation}

Besides natural vegetation, certain tree species were planted along roadsides in the campus and in patches from time to time starting early nineties. Overall, 46 tree species were encountered with 756 individuals. Few notable species include Samanea saman (Jacq.) Merr (21), Schleichera oleosa Lour (58), Leucaena leucocephala (Lam) de Wit (127), Dalbergia paniculata Roxb (35), Zizyphus xylopyrus Retz. Willd (14), Hardwickia binata (05), Tecoma argentia (02), Delonix regia (02), Alstonia scholaris (L.) R. Br. (04), Terminalia arjuna Roxb (02), Tamarindus indica L (02), Pithcelobium dulce Roxb (02), Ailanthus excelsa Roxb (02) Bombax ceiba L (04) and Bamboo clumps (77 individuals of Dendrocalamus strictus (Roxb.) Nees, Bambusa arundinacea (Retz.) Willd and Bambusa vulgaris Schrad. ex J.C.Wendl.). The study conducted by Kotwal et al. (2004) reported 165 individuals of Samanea saman (Jacq.) Merr, which has now been reduced to just 21 numbers. The health of these surviving trees is not good as dead; dying and diseased trees are visible on roadsides. A detailed examination by pathologists and entomologists team is required. Actually, this species requires deep loamy soil and high rainfall whereas available soil is too shallow and rather rocky to support healthy trees of this particular species. This seems to be the most probable reason for the failure of this particular species. Another significant fact about roadside plantation is the proliferation of Leucaena leucocephala (Lam) de Wit due to good natural regeneration. Numbers of individuals of this species have increased from 48 to 127 during the last eighteen years along roadsides. Termite attack also remains a big issue, particularly near the roadside trees. Other species are doing well on the roadside and growing healthy particularly Schleichera oleosa Lour, Dalbergia paniculata Roxb and three bamboo species (Figure 4).

Plantations of different tree species were also raised from time to time in past in small patches of the degraded area like that of Tectona grandis, Hardwickia binata, Pterocarpus marsupium, Emblica officinalis, Samanea saman (Jacq.) Merr, Gardenia latifolia, Santalum album L,
Dalbergia sissoo Roxb, Dalbergia paniculata Roxb, Schleichera oleosa Lour, Ficus religiosa L, Putranjiva parviflora Roxb and the like (Kotwal et al. 2004). Out of above plantations few species are doing well in tough situations of shallow and rocky soil coupled with high summer temperatures sometimes reaching 47-48 degree Celsius, e.g. Hardwickia binata, Santalum album L, Dalbergia paniculata Roxb and Schleichera oleosa Lour. These should be given preference as avenue and grove trees.

A patch of about one acre ( 1 hectare $=2.47$ acre) of Hardwickia binata needs special mention here. Hardwickia binata Roxb. (Anjan) is a leguminous tree species and is reported to enhance land-use efficiency and fulfill multiple demands (timber, fodder and fuel) in arid and semiarid regions (Shanker et al. 2005; Singh and Rathod 2007). This species is not native to this region. The patch of Anjan plantation at IIFM was raised during 1987-88 over more than two acres of area (Figures 5 and 6). Presently slightly above one-acre patch of the plantation is surviving as some area was diverted for the tennis court and cricket ground in the institute a few years ago. Numbers of trees available per acre are around 300 . It is a pure rainfed plantation with about twenty per cent mortality occurring at different periods, and about eighty per cent of trees are still doing well. However the growth is stunted due to poor edaphic factors, i.e. soil and rocky terrain of the site.

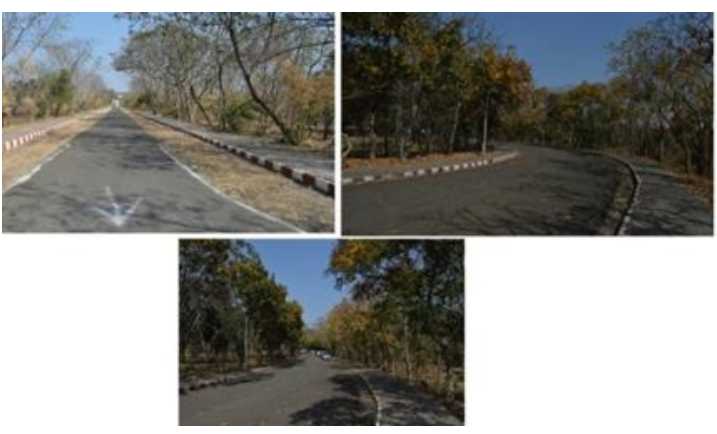

Figure 4. A view of roadside plantation at the study site: Subabul (Leucaena leucocephala), Dhobin (Dalbergia paniculata) and Kusum (Schleichera oleosa) in clockwise direction of arranged photographs

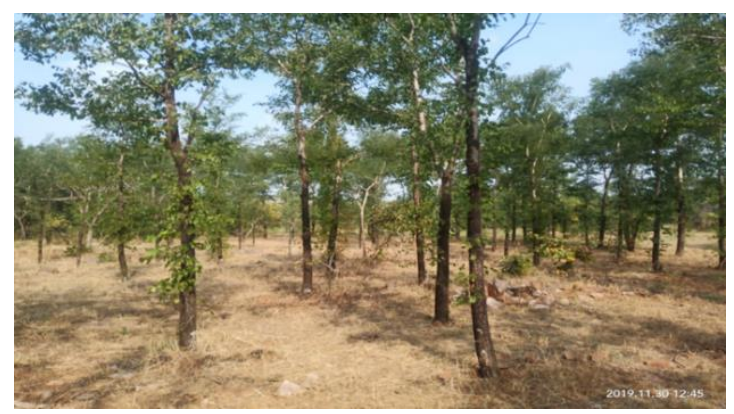

Figure 5. 32-year-old Hardwickia binata Roxb. plantation at IIFM, Bhopal Campus 


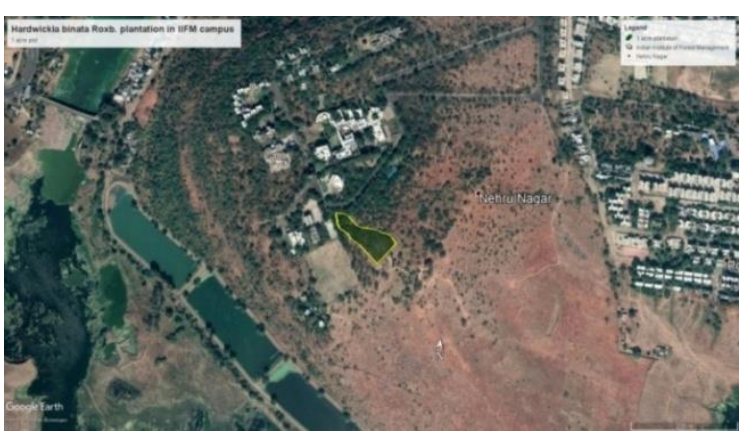

Figure 6. Google Earth top view of IIFM campus along with highlighted Hardwickia binata plantation área

Campus supports conducive environment for tree growth, particularly where soil depth is good, as it could be envisioned through the presence of some rare species during earlier and present studies, e.g. Gardenia gummifera LF, Cochlospermum regiosum (L.) Alston, Crataeva religiosa G.Forst., Grewia tiliifolia Vahl, Randia dumetorum (Retz.) Poir and Celastrus paniculatus Willd. ShannonWiener index for tree species diversity in the present study as 1.31 indicates that the species present in the study area are fairly evenly distributed among all the species in the community. The index ranges between 0.83 and 4.1 , the reported range for this index for the forests of Indian sub-continent (Jha and Singh 1990; Visalakshi 1995; Sahu et al. 2012; Panda et al. 2013). The evenness as 0.85 indicates the relative abundance of the different species contributing to the richness of study area. The extent of dominance (Simpson's Index) estimated as 0.93 is within a range of 0.21-1.34 reported for other forests (Knight 1975; Visalakshi 1995; Naidu and Kumar 2016).

The campus forest and grassland areas are frequented by the number of birds. Few significant birds include Black Drongo, Indian Myna, Grey Shirke, Common Peafowl/ Peacock (national bird of India), White Breasted Kingfisher, Common Grey Hornbill, Crow-pheasant/Coucal, Jungle Babble, Common Baller), Rose-ringed parakeet, Purple-sun-bird etc. The unique landscape of IIFM campus provides a congenial environment for the proliferation of various species of mammals and reptiles also. Common wild mammals observed in the campus include Common mongoose, Hyena, Indian field mouse, Spiny field mouse, Indian hare, Wild cat, Mole and Porcupine. Occasionally, the site is visited by leopard/panther also from nearby Kerwa wildlife sanctuary. Important reptiles of the campus are Indian cobra, Russel viper, Indian python, Monitor lizard, Indian worm snakes and Common Indian Krait (Kotwal et al. 2005).

\section{Conclusion}

There is an urgent need to improve the biodiversity of few left-over green-lungs in big cities amid ever-increasing population and vehicular traffic, industrial pollution in countries like India where human population density is $>400$ $\mathrm{sq} \mathrm{km}^{-1}$. Rich biodiversity is responsible for key ecological processes necessary for sustaining life on the planet. Documenting the patterns of tree diversity, species composition, forest architecture provides a good database which can be used for future management measures of these urban forests. Tree species density, basal area, abundance, species composition, biodiversity indices analyzed in the present study should be useful to the conservation researchers, forest managers and scientists for future forest conservation and effective management.

\section{Acknowledgement}

Authors are thankful to the reviewers for providing positive and constructive comments. Assistance provided by Mr. Vikram Sri Vyas and Rushabh Desadla is duly acknowledged for providing some figures using softwares QGIS and Google Earth Pro.

\section{References}

Bijalwan A (2010) Structure, composition and diversity of degraded dry tropical forest in Balamdi Watershed of Chhattisgarh plain, India. Jornal of Biodiversity, $\quad 1(2): 119-124 . \quad$ Doi: 10.1080/09766901.2010.11884723.

Curtis JT, McIntosh RP (1950) The interrelation of certain analytic and synthetic phytosociological characters. Ecology, 31:434-455. Doi: 10.2307/1931497.

Curtis JT and Cottam G (1956) The use of distance measurement in phytosociological sampling. Ecology, 37:451-460.Doi: 10.2307/1930167.

FSI (2013) State of Forests in India, Report published by Forest Survey of India, Dehradun, India

Ghate U, Joshi NV, Gadgil M (1998) On the patterns of tree diversity in the Western Ghats of India, Current Science, 75:594-603.

Jha CS, Singh JS (1990) Composition and dynamics of dry tropical forest in relation to soil texture. Journal of Vegetation Science, 1:609614.Doi: $10.2307 / 3235566$.

Kotwal PC, Mishra RP (2000) Biodiversity of Indian Institute of Forest Management Campus. Technical Bulletin, Bhopal:IIFM. 1-22p.

Kotwal PC, Dugaya D, Mishra RP (2004) Vegetational studies in natural forest of Indian 
institute of forest management campus Bhopal. My Forest, 40(4):393-403.

Kotwal PC, Dugaya D, Mishra RP (2005) Biodibversity of IIFM Campus. Bhopal: Indian institute of forest management. 44p. ISBN: 817969-021-0.

Knight DH (1975) A phytosociological analysis of species rich tropical forest on Barro Colorado Island, Panama. Ecological Monograph, 45: 259289.Doi: $10.2307 / 1942424$.

Laurance WF (1999) Reflections on the tropical deforestation crisis. Biological Conservation, 91: 109-118.Doi: 10.1016/S0006-3207(99)00088-9.

Misra R (1968) Ecology Workbook. New Delhi: Oxford and IBH Publishing Company. 244-245p.

Murali, KS, Uma S, Shaanker U, Ganeshaiah KN, Bawa KS (1996) Extraction of forest products in the forests of Biligirirangan Hills, India and impact of NTFP extraction on regeneration, population structure, and species composition. Economic Botany, 50:252-269. Doi: 10.1007/BF02907329.

Naidu MT, Kumar OA (2016) Tree diversity, stand structure and community composition of tropical forests in Eastern Ghats of Andhra Pradesh, India. Journal of Asia - Pacific Biodiversity, 9:328-334. Doi: 10.1016/j.japb.2016.03.019.

Panda PC, Mahapatra AK, Acharya PK, Debata AK (2013) Plant diversity in tropical deciduous forests of Eastern Ghats, India: A landscape level assessment. International Journal Biodiversity and Conservation, 5 (10): 625-639.Doi: 10.5897/IJBC2013.0581x.

Pielou EC (1966) The measurement of diversity in different types of biological collections. Journal of Theoretical Biology, 13:131-144.Doi: 10.1016/0022-5193(66)90013-0.

Phillips EC (1959) Methods of Vegetation study. New York: Holt R and Winston. 105p.

Reddy CS, Pattanaik C, Mohapatra A, Biswal AK (2007) Phytosociological observations on the diversity of tropical forest of Simlipal Biosphere Reserve, Orissa, India. Taiwania, 52(4): 352359.Doi: 10.6165/tai.200752(4).352.

Sahu PK, Sagar R, Singh JS (2008) Tropical forest structure and diversity in relation to altitude and disturbance in a Biosphere Reserve in central India. Applied Vegetation Science, 11: 461-470.Doi: 10.3170/2008-7-18537.
Sahu SC, Dhal NK, Mohanty RC (2012) Tree species diversity, distribution and population structure in a tropical dry deciduous forest of Malyagiri Hill ranges, Eastern Ghats, India. Tropical Ecology, 53(2): 163168.

Shanker AK, Newaj R, Rai P, Solanki KR, Kareemulla K, Tiwari R, Ajit (2005) Microclimate modifications, growth and yield of intercrops under Hardwickia binata Roxb. based agroforestry system. Archivesof Agronomy and Soil Science, 51:253-268. Doi: 10.1080/0365034050005340.

Simpson EH (1949) Measurement of diversity. Nature, 163: 688.Doi: 10.1038/163688a0.

Singh G, Rathod TR (2007) Tree and crop growth and soil resource availability in HardwickiabinataRoxb agroforestry systems in the Indian desert. Arid Land Research and Management, 21:193-210. Doi: 10.1080/1532498070142936.

Singh SP, Rawat YS,Garkoti SC (1997) Failure of brown Oak (Quercus semicarpifolia) to regenerate in the Central Himalaya: a case of environmental semi-surprise. Current Science, 73:371-374.

Sundarapandian SM, Swamy PS (1997) Plant biodiversity at low-elevation evergreen and moist deciduous forests at Kodayar (Western Ghats, India). International Journal of Ecology and Environmental Science, 23: 363-379.

Visalakshi N (1995) Vegetation analysis of two tropical dry deciduous forests in Southern India. Tropical Ecology, 36: 117-127. 